\title{
CO2 MARITIME TRANSPORTATION
}

\author{
Sandrine DECARRE ${ }^{a}$, Julien BERTHIAUD ${ }^{b}$, Nicolas BUTIN $^{c}$, Jean-Louis \\ GUILLAUME-COMBECAVE ${ }^{d}$
}

\footnotetext{
${ }^{a}$ Institut Français du Pétrole, IFP, 1 ave Bois Préau, 92500 Rueil Malmaison, FRANCE. Email: Sandrine.Decarre@ifp.fr

${ }^{b}$ GDF SUEZ, 361, ave du Président Wilson, BP 33, 93211 Saint Denis La Plaine cedex, FRANCE. Email: julien.berthiaud@gdfsuez.com

${ }^{c}$ SAIPEM, 1-7 avenue San Fernando 78884 Saint Quentin en Yvelines Cedex FRANCE, .Email: Nicolas.BUTIN@saipem-sa.com

${ }^{d}$ STX France SA, ave Bourdelle, BP 90180, 44613 Saint-Nazaire Cedex France. Email: jean-louis.guillaume-combecave@stxeurope.com
}

International Journal of Greenhouse Gas Control 4(5):857-864 · September 2010

Doi : $10.1016 /$ j.ijggc.2010.05.005

\begin{abstract}
The objective of this study is to describe the complete transport chain of $\mathrm{CO} 2$ between capture and storage including a ship transport. This last one is composed by the following steps:

Shore terminal including the liquefaction, temporary storage and $\mathrm{CO} 2$ loading,

Ship with a capacity of $30,000 \mathrm{~m}^{3}$,

On or off shore terminal including an unloading system, temporary storage and export towards the final storage.

Between all the possible thermodynamic states, the liquid one is most relevant two options are compared in the study $\left(-50^{\circ} \mathrm{C}, 7\right.$ bar $)$ and $\left(-30^{\circ} \mathrm{C}, 15 \mathrm{bar}\right)$. The ship has an autonomy of 6 days, is able to cover $1,000 \mathrm{~km}$ with a cargo of $2.5 \mathrm{Mt} / \mathrm{year}$. Several scenarios are studied varying the geographical position of the $\mathrm{CO} 2$ source, the number of harbours and the way the $\mathrm{CO} 2$ is finally stored.

Depending on the option, the transport cost varies from 24 to $32 € / t C O 2$. This study confirms the conclusion of a previous study supported by ADEME, the cost transport is not negligible regarding the capture one when ships are considered. Transport by ship becomes a more economical option compared with an off shore pipeline when the distance exceeds $350 \mathrm{~km}$ and with an onshore pipeline when it exceeds 1,100 km .
\end{abstract}

\section{KEYWORDS}

$\mathrm{CO} 2$; carbon dioxide; transport; ship; costs; energy 


\section{INTRODUCTION}

An answer to climate change is $\mathrm{CO}_{2}$ capture/transport and storage (CCS). This answer consists in the capture of $\mathrm{CO}_{2}$ from large point sources emissions and the find of safe place to store it. But source and sink are generally far one from the over. To transport large amount of $\mathrm{CO}_{2}$, pipeline seems to be the best solution. And a previous study, Bonnissel et al. [2007] designed a supercritical pipeline and gave cost estimation. But transporting $\mathrm{CO}_{2}$ by ship will be far more flexible and less expensive for long distances. Gas carriers can also be used to collect $\mathrm{CO}_{2}$ from a number of plants for transport to a central staging post connected to an aquifer by an off shore pipeline. Four existing ships, transporting carbon dioxide for use in industry and alimentary processes have small capacities: between 800 and $1,200 \mathrm{~m}^{3}$.

Few economical studies have been realised including a ship transport, Svensson et al. [2007], Aspelund et al. [2006]. In this last one the complete chain is described including the intermediate storage, loading and unloading systems and the ship. A combined $\mathrm{LPG} / \mathrm{CO}_{2} \mathrm{semi}$ refrigerated ship is chosen with a capacity of $20,000 \mathrm{~m}^{3}$ under $\left(-52^{\circ} \mathrm{C}, 6.5 \mathrm{bar}\right)$. A complete energy and cost estimate analysis is performed concluding that the total cost is $20-30 \mathrm{USD} / \mathrm{t}_{\mathrm{CO} 2}$ for volumes larger than $2 \mathrm{Mt} / \mathrm{year}$ and distances limited to North Sea.

This paper presents a complete transportation chain study including $\mathrm{CO}_{2}$ conditioning, pipeline transport, liquefaction, loading/unloading systems, temporary storages and a new 30 $000 \mathrm{~m}^{3}$ ship design. A cost analysis based on three scenarios is also described.

\section{TRANSPORTATION CHAIN DESCRIPTION}

\section{Capture plants and conditioning}

Three flowrates are studied: 1, 2 and $3 \mathrm{Mt} / \mathrm{year}$ (this last one corresponding to a coal steam power plant of $600 \mathrm{MWth})$. For the study, $\mathrm{CO}_{2}$ is considered free of impurities and water. Two $\mathrm{CO}_{2}$ sources locations are considered (Fig. 1):

- a source at $100 \mathrm{~km}$ fare from the harbour. $\mathrm{CO}_{2}$ is transported in a supercritical phase by a 15" internal diameter pipeline. It is delivered at the terminal at 100 bar and at ambient temperature. The gas is available at 1.7 bar with a content of $28 \%$ of water after capture, $\mathrm{CO}_{2}$ conditioning is presented on figure 2 and described in Bonnissel et al. [2007]); The evaluation performed in this study leads to a total cost of $€ 83$ million 
for the compression \& dehydration process, and between $€ 78$ million and $€ 90$ million for the pipeline.

- a source in the harbour area. $\mathrm{CO}_{2}$ is delivered at 1.7 bar; $25^{\circ} \mathrm{C}$, at the liquefaction stage.

\section{Liquefaction, storage and loading}

Between all the possible options of transport we selected two thermodynamic conditions of liquid $\mathrm{CO}_{2}$ : a low temperature to limit tank cost thanks to lower pressure $\left(-50^{\circ} \mathrm{C}, 7\right.$ bar $)$ and a high temperature to limit Energy penalty in the liquefaction plant $\left(-30^{\circ} \mathrm{C}, 15 \mathrm{bar}\right)$. We avoid solid $\mathrm{CO}_{2}$ transport because of the impact on the loading/unloading operations, solid handling being much more difficult than liquid, especially in case of off shore unloading operation.

$\underline{\text { The liquefaction }}$

For both sources the liquefaction chain has been simulated using the software HYSYS.

From a bibliographic study and taking into account the new regulations, two coolers are compared in the study: propane and propylene. Two scenarios of cooling are taken into account (Fig. 3):

- $\mathrm{CO}_{2}$ is first compressed or expanded to reach 7 bar (1 or 2 compressor stages depending on the refrigerant nature) or 15 bar ( 2 or 3 compressors stages depending on the refrigerant nature) then cooled down to $-50^{\circ} \mathrm{C}$ or $-30^{\circ} \mathrm{C}$ and expanded again to be liquefied.

- 2 cooling loops in serial. The first compressor stage provides a $\mathrm{CO}_{2}$ at $-7^{\circ} \mathrm{C}$, which is then expanded down to 30 bar. The second loop cooled down the $\mathrm{CO}_{2}$ to $-30^{\circ} \mathrm{C}$ and the last expansion is realised to reach 15 bar.

Table 1 summarises the energy required for all these options for a source located $100 \mathrm{~km}$ fare from the harbour. It is clear that the options propane, double cooling loops lead to the best scenario. This conclusion is confirmed in case of $\mathrm{CO}_{2}$ capture in the harbour area.

\section{The temporary storage}

To simplify the design and reduce costs, we considered that terminals and ships storage are composed of the same tanks. Storage on terminal is twice the storage on ship. Two designs are possible: cylinder or bilobate (Fig. 4). 
The design satisfy the BS5500 PD code. It is realised with the sailing conditions and takes into account the fact that the boil off shall be neither released to the atmosphere, nor reliquefied. Then a possible pressure increase from 7 to 10.4 for the option $\left(-50^{\circ} \mathrm{C}, 7 \mathrm{bar}\right)$ and from 15 to 19.5 for $\left(-30^{\circ} \mathrm{C}, 15\right.$ bar $)$ and two days of margin in case of bad weather condition are integrated in the design conditions. The design temperature corresponds to the one obtained during a sudden depressurisation and is taken equal to $-80^{\circ} \mathrm{C}$. This critical temperature governs the choice of the quality of the steel: $3.5 \%, 5 \%$ and $9 \% \mathrm{Ni}$; stainless steel 304L and 316L; aluminium 1050. The use of stainless steels and aluminium leads to high thickness and possible construction difficulties. 5 and $9 \% \mathrm{Ni}$ are the best candidates, $5 \% \mathrm{Ni}$ being the cost optimum solution and $9 \% \mathrm{Ni}$ being the weight optimum solution. We chose the $9 \% \mathrm{Ni}$ which leads to smaller supplying delays and is well known by the manufacturers. The optimal solution is a cylindrical tank in steel $9 \% \mathrm{Ni}$, with a casing of $10 \mathrm{~mm}$ thick, full of perlite (Fig. 5).

\section{The loading process}

In order to transfer the liquefied $\mathrm{CO}_{2}$ from the temporary storage to the ship, a system of pumps and flexible or rigid arm (piping) is designed. These lines have a diameter of 16" and a length of $120 \mathrm{~m}$. Pressures need to be equilibrated between both storages as the boil off $\left(\mathrm{CO}_{2}\right.$ evaporation) generated during the loading operation increases the ship tank pressure. The gas generated is sent back to the liquefaction unit by a second line (Fig. 6).

\section{Ship description}

Gas is usually transported under its liquid phase, than means under low temperature. As the ship is specified without any re-liquefaction plant onboard, tanks are designed to resist to the pressure increase.

Specifications for the ship are:

- A capacity of $30,000 \mathrm{~m}^{3}$,

- Process for a loading and unloading with an onshore terminal,

- Pumps with a total power of 5.2 MW, for an offshore unloading,

- Dynamic position for offshore unloading,

- The most economical propulsion in order to reach a speed of 16.5 knots. 
- Following the existing regulations: SOLAS (Safety Of Life At Sea), IGC (Ship Carrying Liquefied Gas in Bulk) and MARPOL (MARitime POLution).

Based on these specifications a ship is designed (Fig. 7). 7 tanks, as the one presented previously, are integrated. Cofferdams $(600 \mathrm{~mm})$ are placed between the tanks and the front and back parts of the ship in order to limit thermal exchanges and allow inspections. Possible dilatation of the tanks was considered in the design of a new fixing system including wood parts.

Different solutions for the propulsion are considered:

\begin{tabular}{|c|l|l|}
\hline Architecture & \multicolumn{1}{|c|}{ advantages } & \multicolumn{1}{|c|}{ disadvantages } \\
\hline Electric-diesel & $\begin{array}{l}\text { Better consumption, } \\
\text { architecture optimisation, } \\
\text { low power installed }\end{array}$ & $\begin{array}{l}\text { CAPEX high, complexity } \\
\text { (higher breakage risk), site } \\
\text { coverage consuming }\end{array}$ \\
\hline $\begin{array}{c}\text { Diesel (type CODAD, } \\
\text { COmbinaison Diesel } \\
\text { Alternateur Diesel) }\end{array}$ & $\begin{array}{l}\text { CAPEX, well known } \\
\text { technology, less breakage } \\
\text { risk than electric-diesel }\end{array}$ & $\begin{array}{l}\text { OPEX (higher } \\
\text { consumption than electric- } \\
\text { diesel) }\end{array}$ \\
\hline 2T motors & $\begin{array}{l}\text { CAPEX, well known } \\
\text { technology, OPEX }\end{array}$ & $\begin{array}{l}\text { Pollution, no dynamic } \\
\text { position, heavy. }\end{array}$ \\
\hline
\end{tabular}

The best option is the electric-diesel but could be considered as too much expensive by the future clients for sequestration operations. Then a more classical architecture like the CODAD type (diesel) is our final choice. Two motors, fed by heavy fuel oil, will be connected to an adjustable blade propeller (Diameter $7 \mathrm{~m}$ ). The energy necessary on board will be provided by four diesel alternators.

Installation of the different utilities on board is realised in parallel with the stability analysis of the ship. The stability analysis is realised using the software ARGOS with a working load from $10 \%$ to $100 \%$ (tank full at $95 \%$, keeping a volume for the boil off). It takes into account the new regulations on biologic prevention pollution (ballast are full of water, their loading procedures are described) and the IGC code relative to possible damages. As the ship as an axial symmetry, all the damages are simulated at port on a watertight bulkhead. ARGOS simulations show that IGC criteria are completely respected. 


\section{On or Off- shore unloading}

- Onshore terminal

This terminal is similar to the loading one. Temporary storage will be twice the one present on the ship in order to have a safety margin, this hypothesis could be optimised integrating the management of a complete fleet of $\mathrm{CO}_{2}$ ships. Possible reuse of the liquid $\mathrm{CO}_{2}$ frigories will have to be integrated in a more detailed study.

- Offshore unloading

Between all the possibilities a direct unloading is considered. In order to fit with the constraints: maximum time on place 24 hours in the North Sea, injection power of 5.2 MW for $30,000 \mathrm{~m}^{3}$ of $\mathrm{CO}_{2}$ at $-30^{\circ} \mathrm{C}, 15$ bar (Fig. 8). To be able to respected them, 4 wells are necessary to achieve a flowrate of $350 \mathrm{t} / \mathrm{h}$, maximum value tolerated by the aquifer. Conditions imposed at the well head are $0^{\circ} \mathrm{C}$ and $110 \mathrm{bars}$. Pumps on the ship will furnish the energy to reach 95 bara, the static pressure over the $200 \mathrm{~m}$ water depth, will complete it. During this phase, $\mathrm{CO}_{2}$ temperature increases a bit. To avoid more energy consumption and $\mathrm{CO}_{2}$ release, $\mathrm{CO}_{2}$ is naturally heated by thermal exchange between a Bare pipe and sea water, before reaching the well head. To increase thermal exchanges the pipe (X60) is not buried and is only coated against the corrosion. Due to the very low temperature at the inlet of the pipe, some ice will form on external pipe wall over few kilometres. Table 2 summarises different possibilities depending on currents and internal pipe diameter. The optimum between steel mass and pressure drop leads to the choice of a 10" NPS (internal diameter of 10") for a designing pressure of 180 bar. Assuming the minimal external temperature of $6^{\circ} \mathrm{C}$ (winter North sea), less than ten kilometres are necessary to reach $0^{\circ} \mathrm{C}$. Weaknesses of this solution are the embrittlement of the pipe due to freeze/thaw cycles, the sensibility to currents, regulations obliging the burrial of the pipes. Simulations, adding a temporary storage (on plateforme or subsea) have been realised. Such solutions are possible, but with weak points such as the necessity of an high floor space, ballasts and subsea structure appear. Other kind of solutions could be used depending on the existing installations: use of a jacket for mooring, CALM systems (Catenary Anchor-Leg Mooring),etc. CALM buoys are frequently used in offshore industry for the oil offloading of floating production facilities. In TransCO $\mathrm{CO}_{2}$ case, $\mathrm{CO}_{2}$ carrier is moored to the CALM buoy the liquid $\mathrm{CO}_{2}$ is transferred from the carrier to the injection network with floating hose. For this solution there is a need for development concerning low temperature and 
high pressure flexible. A solution without mooring structure can be envisaged but required a dynamic positioned (DP) vessel. This kind of vessel is equipped with thrusters ensuring the perfect positioning of the vessel over the injection location. DP vessels are commonly used for the installation of subsea pipelines and drilling rig, but they are fuel consuming degrading the carbon balance of the $\mathrm{CO} 2$ transport. These solutions are compared in the following table:

\begin{tabular}{|l|l|l|}
\hline \multicolumn{1}{|c|}{ Mooring type } & \multicolumn{1}{|c|}{ advantage } & \multicolumn{1}{c|}{ weakness } \\
\hline No mooring structure & Vessel with dynamic positioning & $\begin{array}{l}\text { fuel consuming } \\
\mathrm{CO}_{2} \text { emission } \\
\text { Weather dependant }\end{array}$ \\
\hline CALM system & $\begin{array}{l}\text { control of ship position } \\
\text { weather independent } \\
\text { Well known technology }\end{array}$ & $\begin{array}{l}\text { Mooring assistance } \\
\text { Space consuming }\end{array}$ \\
\hline Disconnectable mooring plug & $\begin{array}{l}\text { control of ship position } \\
\text { weather independent } \\
\text { self governing mooring } \\
\text { control of ship position } \\
\text { Jacket }\end{array}$ & $\begin{array}{l}\text { weather independent } \\
\text { Re use of existing structure }\end{array}$ \\
\hline
\end{tabular}

\section{SCENARIOS}

The basic harbour is composed of

- liquefaction part: centrifugal compressors, plate heat exchanger, vertical centrifugal pump (high flow rate, axial flux), cooler boxes and additional pumps.

- storage: 14 tanks, lines between storage (on terminal or on ship) and liquefaction unit (boil off treatment), flexible or rigid arm, transfer pump.

Depending on the scenario, functionalities on the harbour will be adjusted.

Three scenarios are compared (Fig. 9):

1. 2 harbours $\mathrm{A}$ and $\mathrm{B}, \mathrm{B}$ having a direct connection by pipe $(200 \mathrm{~km})$ to an off shore aquifer. A liquefaction unit is present on B. 
2. 2 harbours $\mathrm{A}$ and $\mathrm{B}$, there is no liquefaction unit on $\mathrm{B}$. Then ambient temperature of the $\mathrm{CO}_{2}$ coming from the on shore pipe and directly connected to the off shore pipe is used to heat the $\mathrm{CO}_{2}$ coming from the ship.

3. 3 harbours $\mathrm{A}, \mathrm{B}$ and $\mathrm{C}$. A and $\mathrm{B}$ correspond to the basic case, $\mathrm{C}$ is connected to an off shore aquifer by a pipe and doesn't have a liquefaction unit. These last case could be representative of a French, English and Dutch case.

\section{Cost estimate}

An economical study is performed on the scenarios previously described. For this estimation the complete transport chain is considered: conditioning of the $\mathrm{CO}_{2}$ at the outlet of the capture unit (only dehydratation and compression), $100 \mathrm{~km}$ on-shore pipe in supercritical conditions (180 bar), liquefaction unit, temporary storage, ship transport covering 1,000 km, unloading in an offshore pipe for final storage. Economic depreciation is supposed to be $5 \%$ over 30 years. Costs for the conditioning and the on shore transport are based on a previous study supported by ADEME (Bonnissel et al., 2007). and based on Chauvel cotations (Chauvel, 2003).

For both solution $\left(-50^{\circ} \mathrm{C}, 7 \mathrm{bar}\right)$ and $\left(-30^{\circ} \mathrm{C}, 15 \mathrm{bar}\right)$, the total cost (CAPEX and OPEX) of the installations from the outlet of the capture plant to the inlet of the temporary storage (conditioning, transport and liquefaction ) showed that the $\left(-30^{\circ} \mathrm{C}, 15\right.$ bar) case was the cheapest one. Then scenarios were estimated only for this option.

For the liquefaction the case $\left(-30^{\circ} \mathrm{C}, 15\right.$ bar $)$ and 2 cooling loops is considered.

\begin{tabular}{|l|l|c|c|}
\hline \multicolumn{1}{|c|}{ Transport chain } & \multicolumn{1}{c|}{ description } & \multicolumn{1}{c|}{$\begin{array}{c}\text { Cost M€/year } \\
\text { (Economic depreciation } \\
\text { 5\% over 30 years) }\end{array}$} & $\begin{array}{c}\text { Source } \\
\text { (Year price) }\end{array}$ \\
\hline CO2 conditioning & Dehydratation, compression & 18 & 2005 \\
\hline On shore transport & On-shore pipe & 9 & 2005 \\
\hline Liquefaction unit & Compressors, heat exchangers, pumps... & 4 & 2005 \\
\hline Storage & 14 tanks & 7.1 & negligible \\
\hline Loading/unloading & Pump, loading arm, transfer lines & 39.3 & 2008 \\
\hline Ship & Ship with 7 tanks & 13 & 2008 \\
\hline Injection & $\begin{array}{l}\text { Heating, heat exchangers, pump } \\
\text { Subsea flow line }\end{array}$ & & 2007 \\
\hline
\end{tabular}


Figure 10 present costs obtained for the three scenarios. Ship transport represents the most expensive part in the chain. However all the expenses linked with a normal ship exploitation are taken into account within this cost i.e. the one of the ship, the expenses for her maintenance, the crew, tax, insurance, harbours ... The conditioning part is under estimated as it is composed in our examples of only the dehydratation and the compression units. In reality, impurities will have to be treated too, increasing the final cost of the conditioning part.

Respectively for the scenarios 1,2 and $3,24 € / t_{\mathrm{CO} 2}, 22 € / \mathrm{t}_{\mathrm{CO} 2}$, and $32 € / \mathrm{t}_{\mathrm{CO} 2}$ are obtained. This confirms that transport cost is not negligible when it integrates a ship part.

A comparison between ship transport and on or off shore pipe is performed. Depending on the $\mathrm{CO}_{2}$ quantity, more than one ship can be considered. $\mathrm{CO}_{2}$ source is considered to be in the harbour area and then only the $\mathrm{CO}_{2}$ conditioning, liquefaction and storage are considered. Cost for the pipe onshore are those considered in the previous study (Bonnissel, 2007). Figure 11 presents the results of this comparison. 4 quantities of $\mathrm{CO}_{2}$ are simulated $(0.8 ; 1.6 ; 2.8 ; 5.6$ $\mathrm{Mt} / \mathrm{year}$ ). Discontinuities of the lines are due to the fact that only a whole number of ships can be added. Clearly our $30,000 \mathrm{~m}^{3}$ ship is over estimated for the $0.8 \mathrm{Mt} /$ year and at least two ships are necessary to transport 5.6 Mt/year. Then compared to a pipeline ship is a more economical solution when distance between two harbours exceed about 1,100 km (onshore pipe comparison), and exceed $350 \mathrm{~km}$ compared to an offshore pipeline (export towards an offshore aquifer).

\section{CONCLUSION}

Ship transport is a flexible alternative to pipeline for an offshore storage option, even for a harbour to harbour transport. It can be cost attractive for long distances $(350 \mathrm{~km}$ for an offshore storage, $1,100 \mathrm{~km}$ for a coast to coast case). Compared with the pipe option. This technical-economics study shows the feasibility to build and use a $30,000 \mathrm{~m}^{3}$ ship to transport $\mathrm{CO}_{2}$ under $\left(-30^{\circ} \mathrm{C}, 15\right.$ bar). Cost estimation leads to a transport cost from 24 to $32 € / \mathrm{t}_{\mathrm{CO} 2}$ covering the chain from the capture outlet to the injection in an offshore aquifer. 


\section{ACKNOWLEDGEMENT}

This study is a co-operation project between IFP (Institut Français du Pétrole), GDF SUEZ, SAIPEM and STX France SA with the financial support of ANR (Agence Nationale de la Recherche).

\section{REFERENCES}

Aspelund A, Mølnvik M. J. And De Koeijer G., "Ship Transport Of Co2 Technical Solutions and Analysis of Costs, Energy Utilization, Exergy Efficiency and CO2 Emissions". Chemical Engineering Research and Design, 84(A9), 2007, pp 847-855.

Bonnissel M., Broutin P., Fradet A., Odru P., Ruer J., Saysset S., "Technical and economic assessment of $\mathrm{CO} 2$ transportation for CCS purposes". The Journal of Pipeline Engineering, Vol. 6, No 3, 2007, pp. 173-179.

Chauvel A., Fournier G., Raimbault C., "Manual of process economic evaluation" (new, revised and expanded edition). Éditions Technip, Paris, 2003.

Svensson, R., Odenberger, M., Johnsson, F., Strömberg, L., "Transportation Infrastructure for CCS - Experiences and Expected Development". Chalmers University of Technology and Vattenfall, Sweden, 2007. 


\section{FIGURES CAPTION}

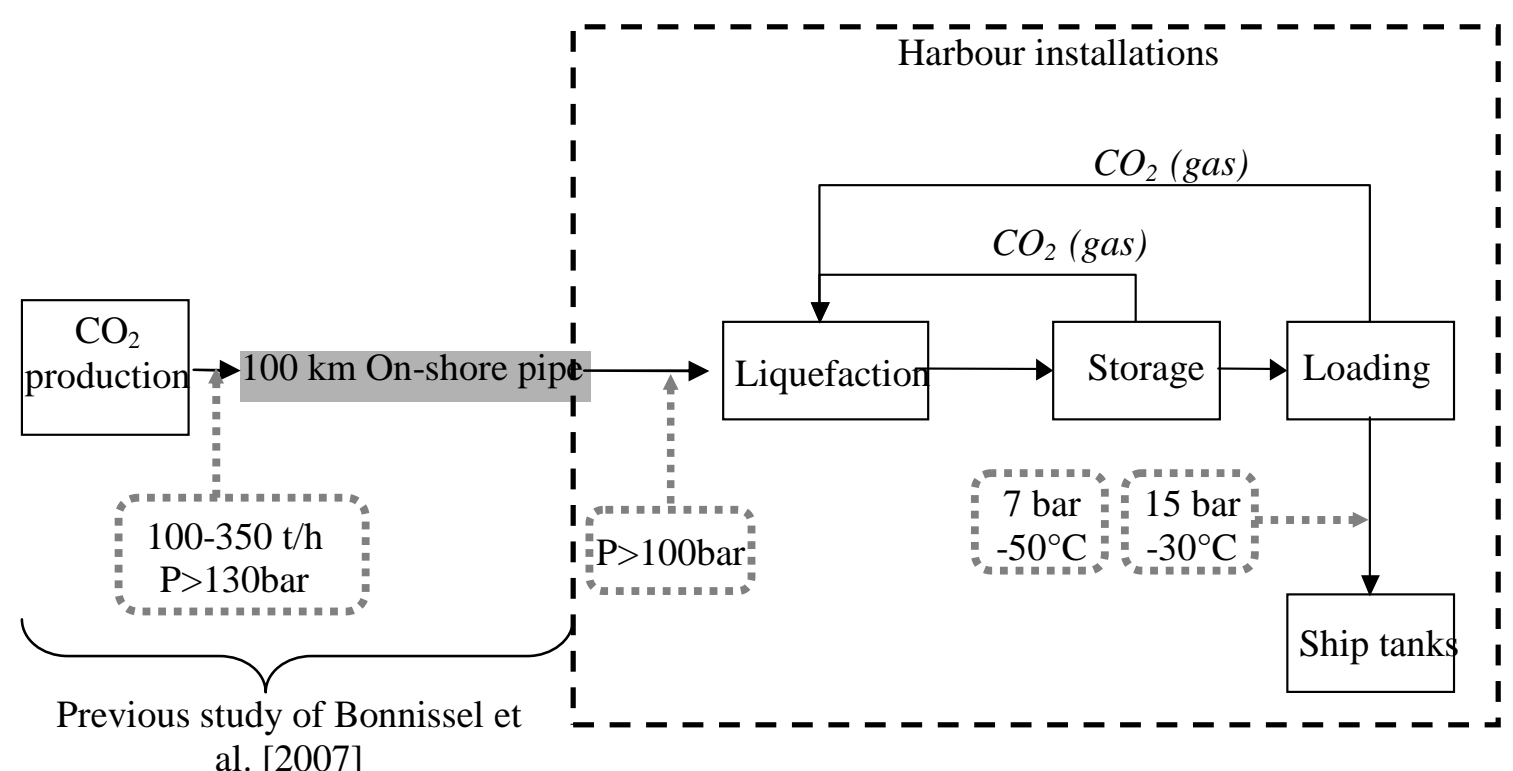

Figure 1: Basic cases

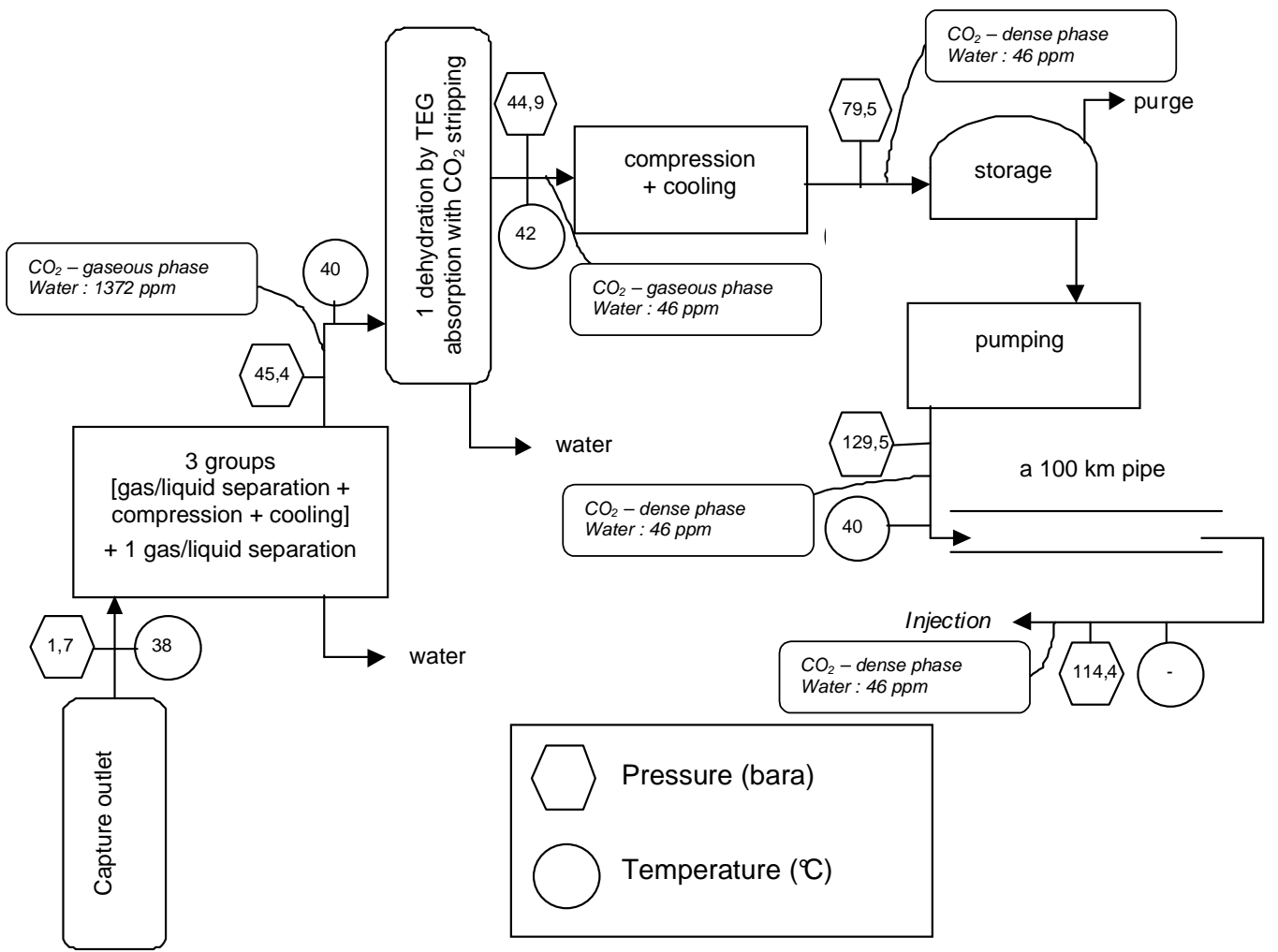

Figure 2: Process flow diagram for the dense phase case 


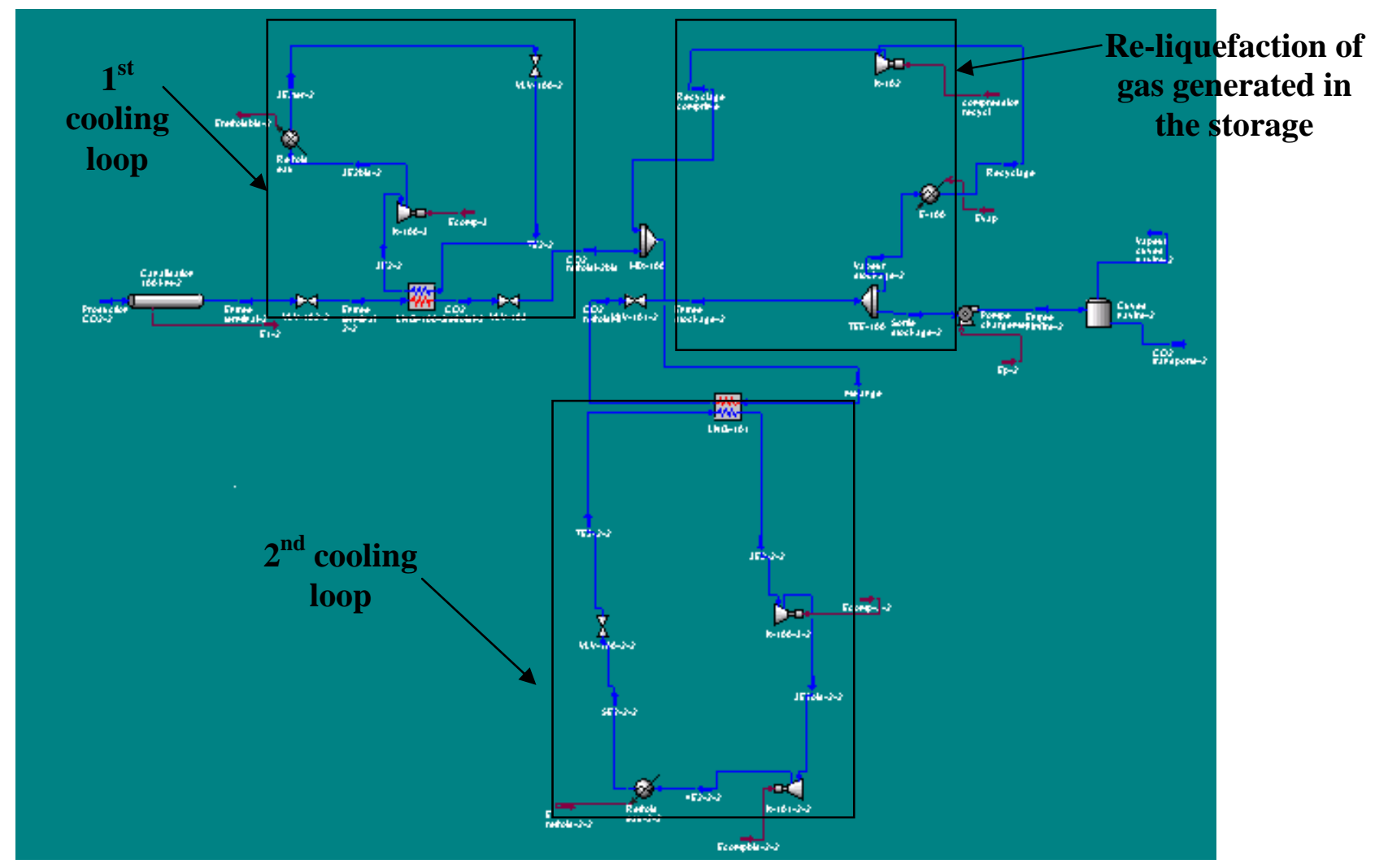

Figure 3: Liquefaction unit
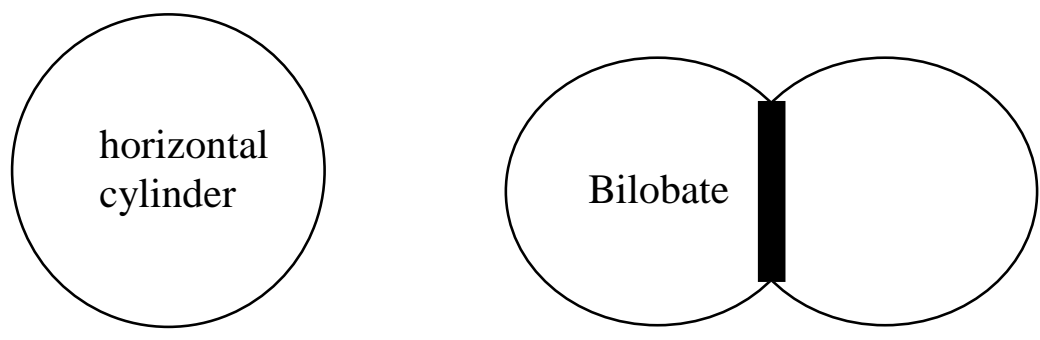

Figure 4: Possible tanks for CO2 temporary storage.

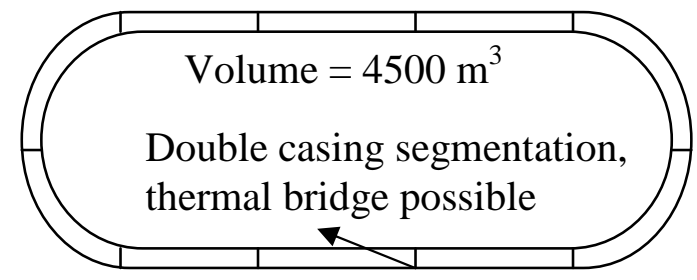

Figure 5 Intermediary storage characteristics. A $4500 \mathrm{~m}^{3}$ tank composed of a double casing containing Perlite vacuum packed (thickness $30 \mathrm{~cm}$ ), having an external diameter of $14.7 \mathrm{~m}$ for $32.3 \mathrm{~m}$ length. 


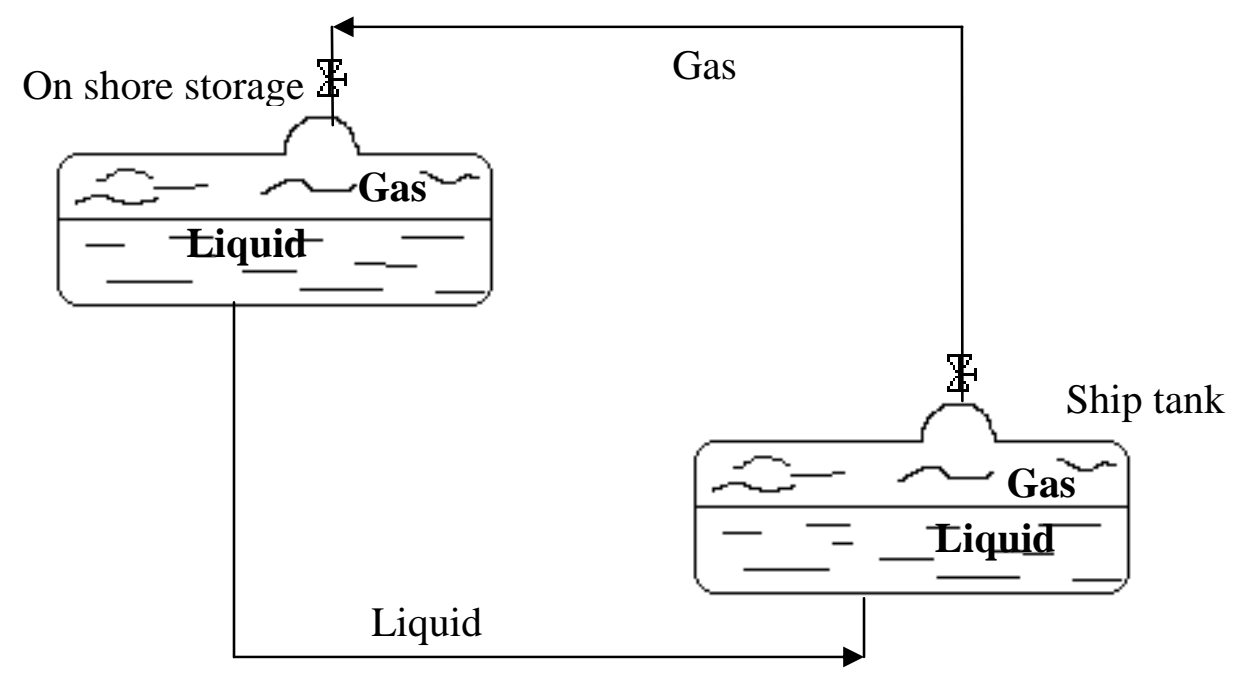

Figure 6: Boil off management during the loading process.
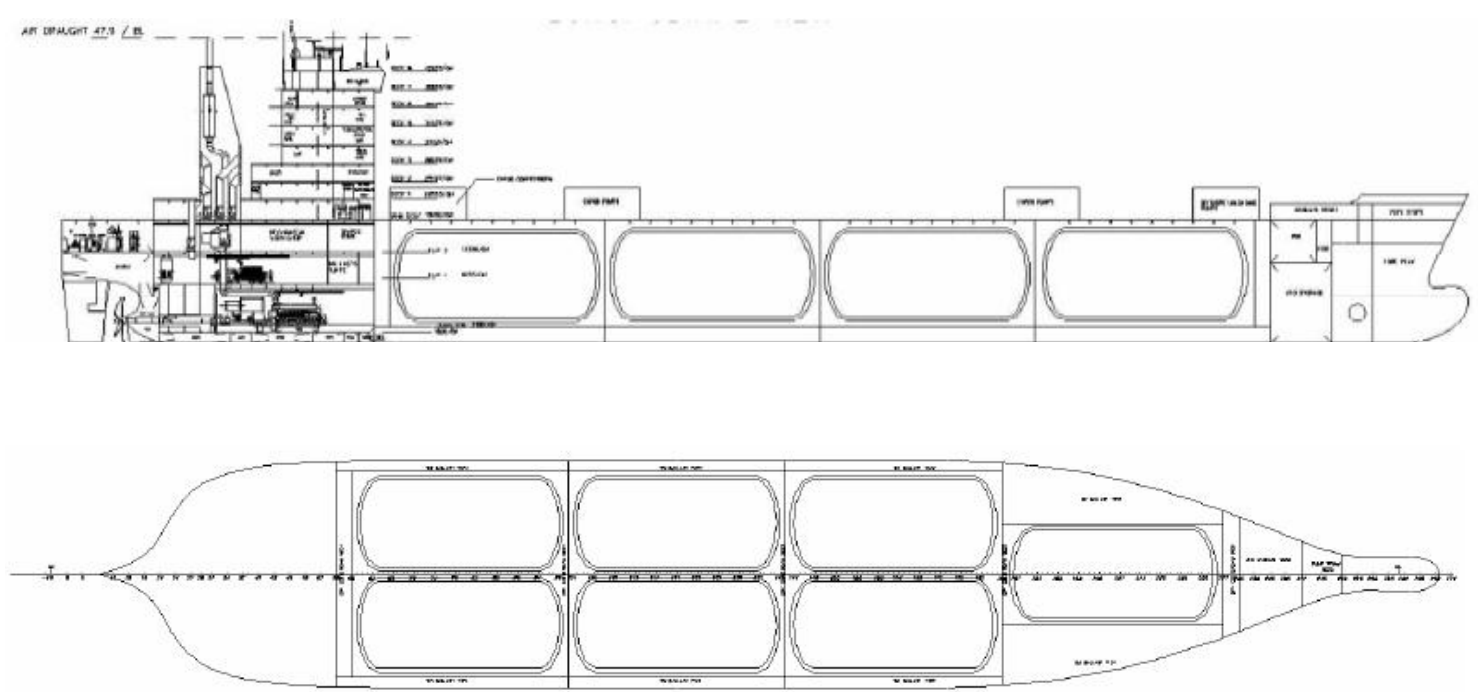

Figure 7: Typical arrangements for a $\mathrm{CO} 2$ ship.

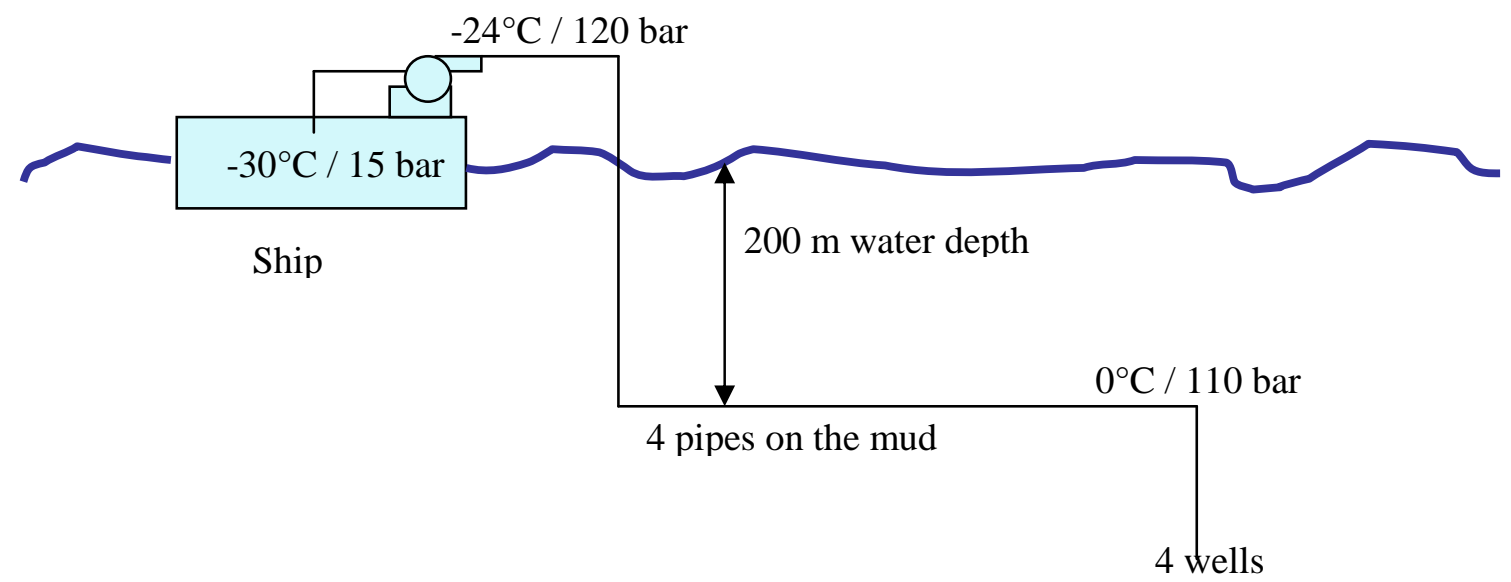

Figure 8: Offshore unloading 
Case 1

2 harbours / 1 ship

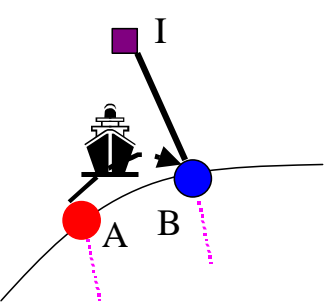

Case 2

2 harbours / 1 ship

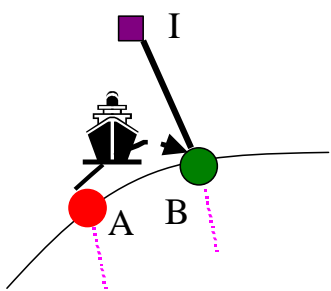

Case 3

\section{3 harbours / 2 ships}

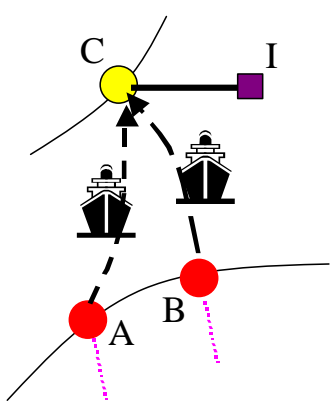

Legend :

Harbour for $\mathrm{CO}_{2}$ transport by ship (liquef action unit $\theta$, storage

Harbour for $\mathrm{CO}_{2}$ injection (liquef action unit $\mathrm{\theta}$, unloading $\boldsymbol{\Lambda}$, storage $\&$ injection)

Harbour for $\mathrm{CO}_{2}$ injection (unloading $\boldsymbol{A}$, storage \& injection)

$\bigcirc$ Harbour for $\mathrm{CO}_{2}$ injection (unloading $\mathcal{A}$, storage $\&$ injection)

$\square$ Injection I

$\stackrel{\text { S }}{\text { i } \rightarrow \text { Ship }}$

........ On-shore pipe

Coast

Figure 9: Use cases

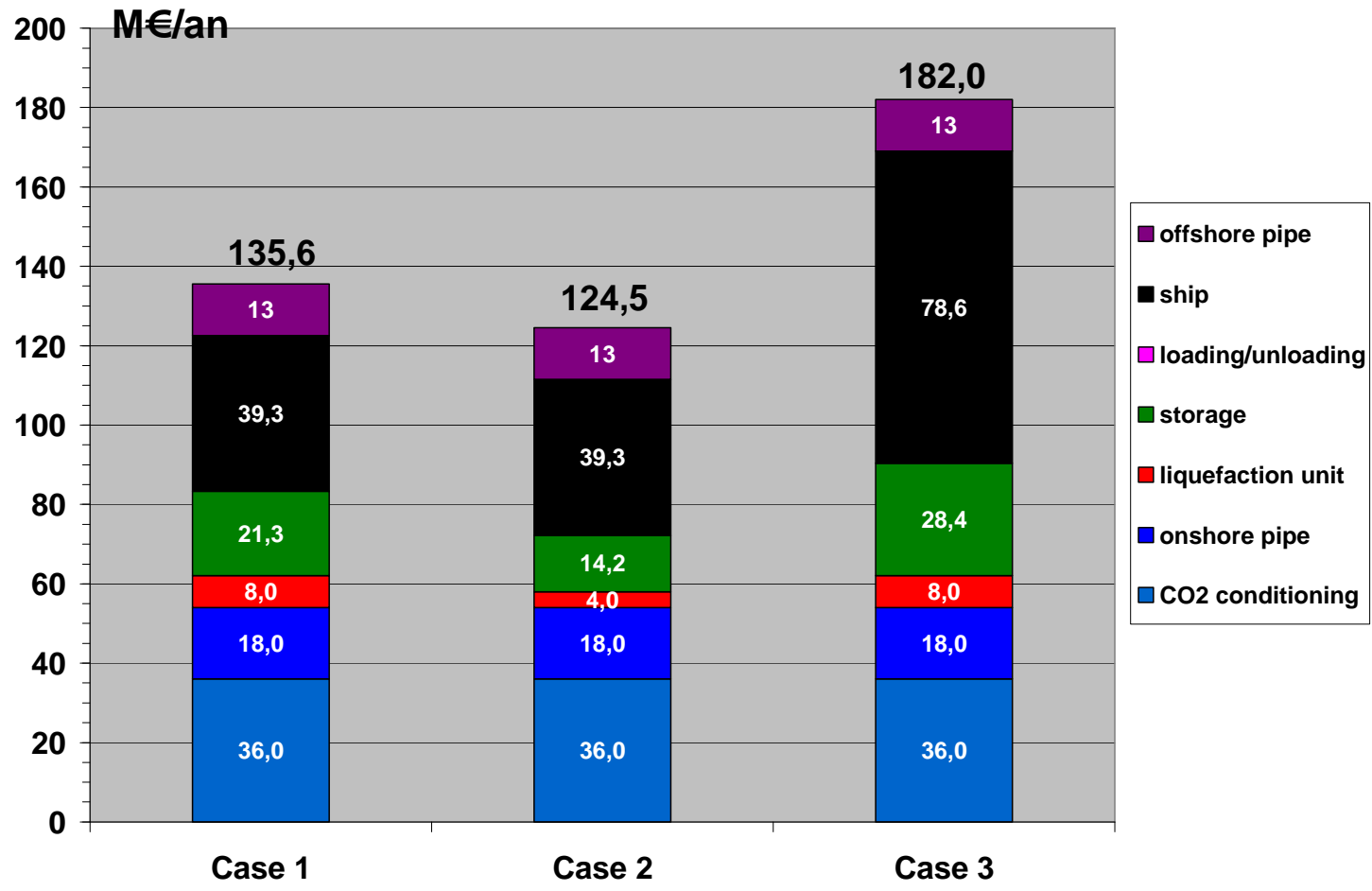

Figure 10: Scenarios costs evaluation 

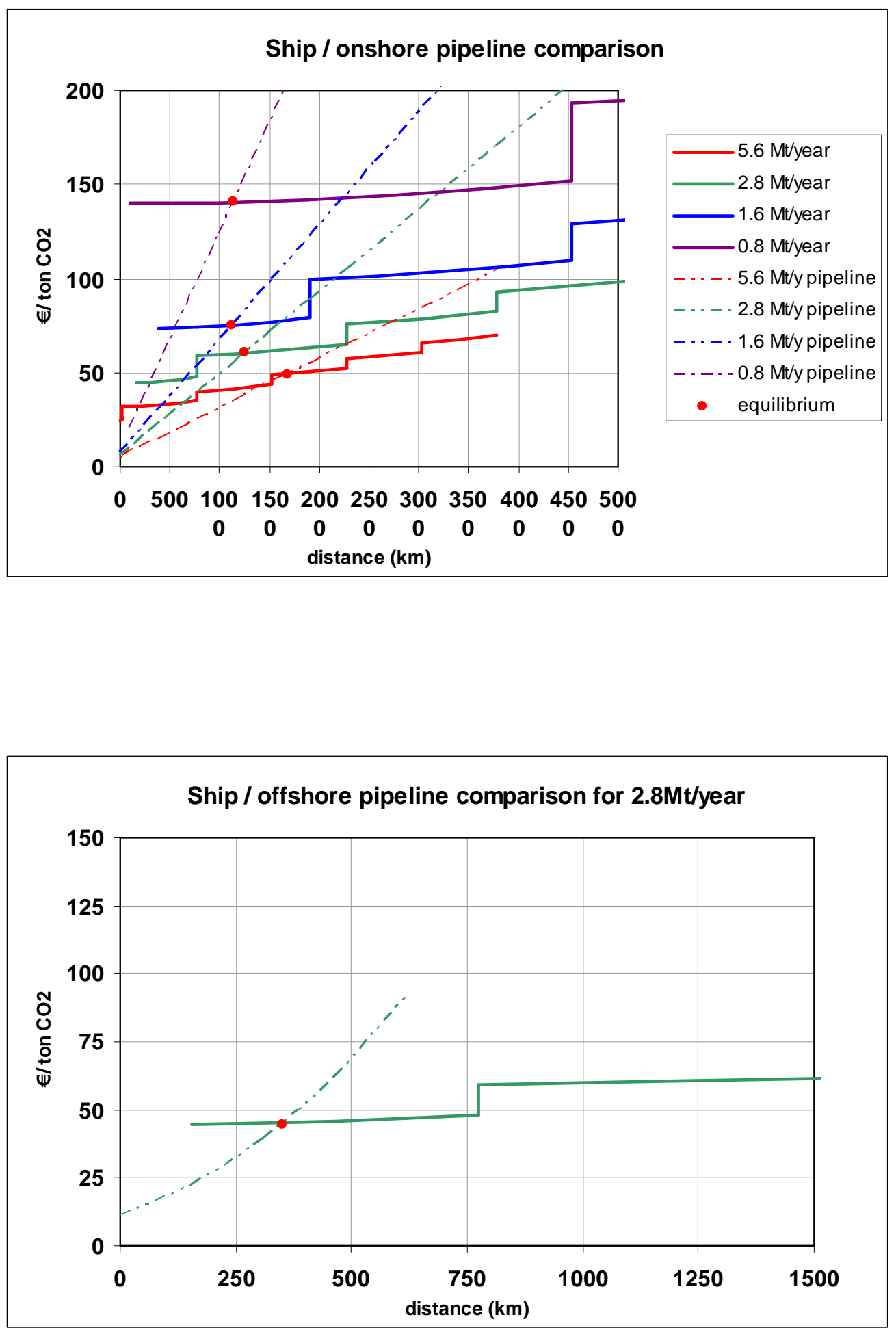

Figure11: Ship/pipeline comparison 


\section{TABLES}

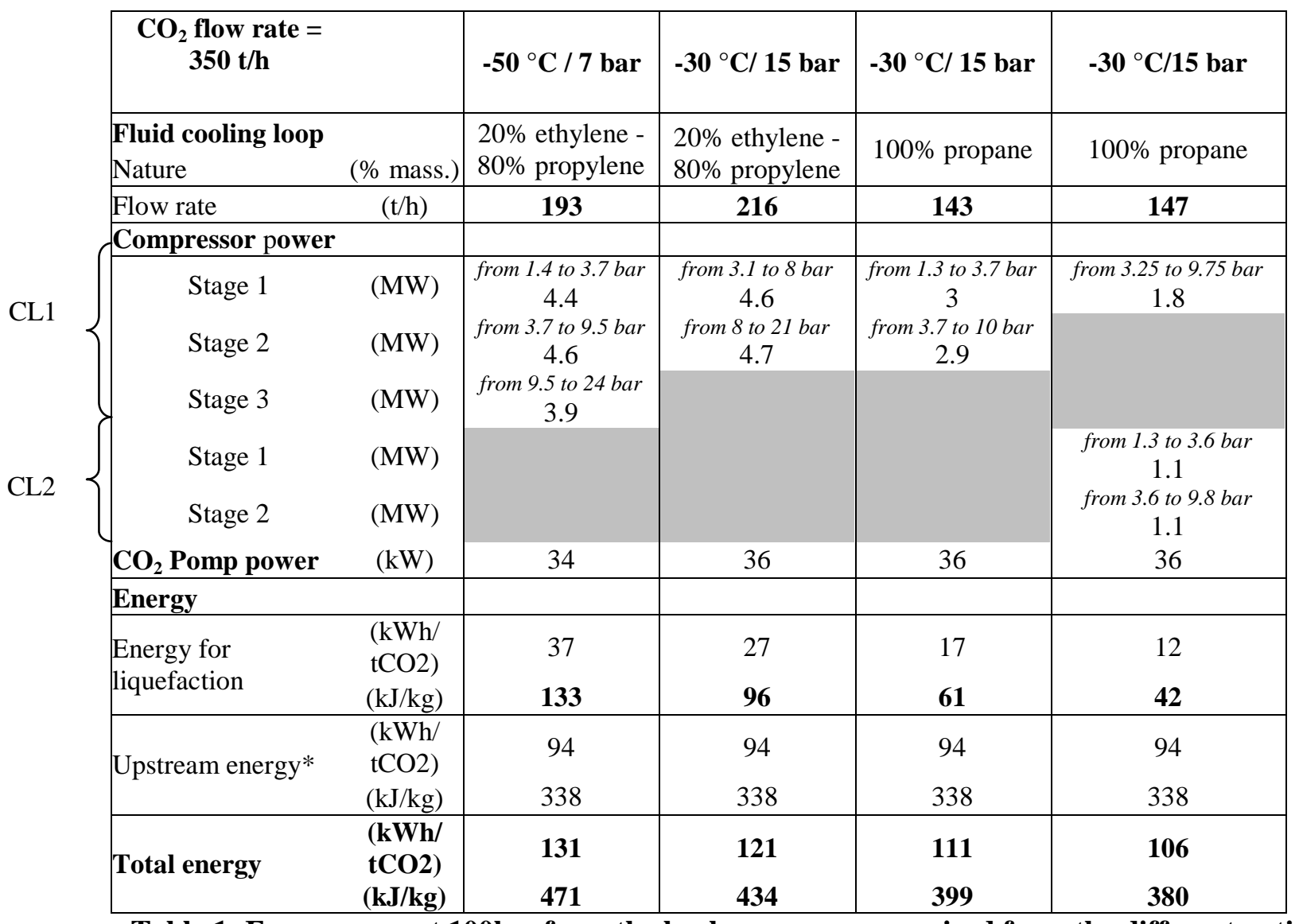

Table 1: For a source at 100km from the harbour, energy required from the different options.

(* Energy for dehydratation and compression before entering the $100 \mathrm{~km}$ pipeline)

\begin{tabular}{|c||c|c|c|c|c|c|c|c|}
\cline { 2 - 11 } \multicolumn{1}{c|}{} & \multicolumn{8}{c|}{ Solution with 4 injection lines } \\
\hline flow rate per well $(\mathrm{bpd})$ & $\mathbf{4 9 5 2 8}$ & 49528 & $\mathbf{4 9 5 2 8}$ & 49528 & $\mathbf{4 9 5 2 8}$ & 49528 & $\mathbf{4 9 5 2 8}$ & 49528 \\
\hline External current velocity $(\mathrm{m} / \mathrm{s})$ & $\mathbf{0 . 0 0 5}$ & 0.5 & $\mathbf{0 . 0 0 5}$ & 0.5 & $\mathbf{0 . 0 0 5}$ & 0.5 & $\mathbf{0 . 0 0 5}$ & 0.5 \\
\hline Pump outlet temperature $\left({ }^{\circ} \mathrm{C}\right)$ & $\mathbf{- 2 2}$ & -23 & $\mathbf{- 2 3 . 7}$ & -24.2 & $\mathbf{- 2 4 . 2}$ & -24.4 & $\mathbf{- 2 4 . 4}$ & -24.5 \\
\hline Internal diameter $(")$ & $\mathbf{8}$ & 8 & $\mathbf{1 0}$ & 10 & $\mathbf{1 2}$ & 12 & $\mathbf{1 4}$ & 14 \\
\hline Pressure drop $(\mathrm{bar})$ & $\mathbf{2 1 . 0}$ & 9.0 & $\mathbf{6 . 2}$ & 2.4 & $\mathbf{2 . 2}$ & 0.7 & $\mathbf{0 . 9}$ & 0.3 \\
\hline Subsea pipe length $(\mathrm{km})$ & $\mathbf{7}$ & 3 & $\mathbf{6 . 5}$ & 2.5 & $\mathbf{6}$ & 2 & $\mathbf{5 . 5}$ & 2 \\
\hline Ice deposition length $(\mathrm{km})$ & $\mathbf{3}$ & & $\mathbf{3}$ & & $\mathbf{3}$ & & $\mathbf{2 . 5}$ & \\
\hline Injection temperature $\left({ }^{\circ} \mathrm{C}\right)$ & $\mathbf{0 . 1}$ & -0.4 & $\mathbf{0 . 0}$ & -0.6 & $\mathbf{0 . 0}$ & -1.6 & $\mathbf{- 0 . 1}$ & -0.3 \\
\hline $\mathrm{CO}_{2}$ velocity $(\mathrm{m} / \mathrm{s})$ & $\mathbf{2 . 8}$ & 2.8 & $\mathbf{1 . 8}$ & 1.8 & $\mathbf{1 . 2}$ & 1.2 & $\mathbf{0 . 9}$ & 0.9 \\
\hline Steel mass $(\mathrm{t})$ & $\mathbf{6 7 1}$ & 288 & $\mathbf{9 7 4}$ & 375 & $\mathbf{1 2 9 5}$ & 432 & $\mathbf{1 6 1 6}$ & 587 \\
\hline Pipe volume $(\mathrm{m} 3)$ & $\mathbf{9 0 8 . 0}$ & 389.2 & $\mathbf{1 3 1 7 . 4}$ & 506.7 & $\mathbf{1 7 5 1 . 2}$ & 583.7 & $\mathbf{2 1 8 4 . 9}$ & 794.5 \\
\hline Topside pump power $(\mathrm{MW})$ & $\mathbf{5 . 4 3}$ & 5.55 & $\mathbf{5 . 1 8}$ & 4.76 & $\mathbf{4 . 7 3}$ & 4.58 & $\mathbf{4 . 5 9}$ & 4.53 \\
\hline
\end{tabular}

Table 2: Pipe length necessary to reach the injection conditions. 